\title{
Effect of the ovulatory follicle diameter and progesterone concentration on the pregnancy rate of fixed-time inseminated lactating beef cows
}

\author{
Luiz Francisco Machado Pfeifer ${ }^{1}$, Sofia del Carmen Bonilla de Souza Leal ${ }^{2}$, Augusto \\ Schneider ${ }^{2}$, Eduardo Schmitt ${ }^{2}$, Marcio Nunes Corrêa ${ }^{2}$
}

${ }^{1}$ Embrapa Rondônia; Porto Velho, RO, Brasil.
2 Departamento de Clínicas Veterinária, Universidade Federal de Pelotas, Pelotas, RS, Brasil.

\begin{abstract}
The objective of this study was to evaluate the influence of the ovulatory follicle diameter on the reproductive performance of lactating beef cows subjected to low progesterone fixed-time artificial insemination (FTAI) protocols. Ninety-three lactating beef cows (60-80 days postpartum) at random stages of estrous cycle were given a luteolytic dose of prostaglandin F2 $\alpha$ (500 $\mu \mathrm{g}$ cloprostenol; PGF) twice, $11 \mathrm{~d}$ apart. Ten days after the second PGF treatment, cows were given $1.5 \mathrm{mg}$ of estradiol benzoate im and a progesterone-releasing intravaginal device (Cue-Mate) with a single pod containing $0.78 \mathrm{~g}$ progesterone (Day 0). Cows received another luteolytic dose of PGF on Day 0. On Day 8, the Cue-Mate was removed Fifty-four to 56 hours later, cows received $12.5 \mathrm{mg}$ of porcine $\mathrm{LH}(\mathrm{pLH})$ i.m. and were concurrently artificially inseminated. Ultrasound examinations of the ovaries were performed on Days 10 and 17 to evaluate the diameter of ovulatory follicle and corpus luteum, respectively. Cows which presented ovulatory follicle $>19 \mathrm{~mm}$ resulted in larger corpus luteum than cows that had ovulatory follicle $<15 \mathrm{~mm}$ in diameter. However, cows with ovulatory follicle between $13-15 \mathrm{~mm}$ had higher pregnancy rate than other categories of ovulatory follicle. Although larger ovulatory follicles result in larger corpus luteum and consequently higher progesterone production, the optimal size of ovulatory follicles $(13-15 \mathrm{~mm})$ may result in positive benefits on pregnancy rate for cows subjected to FTAI with low progesterone concentration protocols.
\end{abstract}

Key Words: corpus luteum, fertility, post-partum cows, progesterone

\section{Introduction}

Despite being widely studied, fertility in fixed time artificial insemination (FTAI) protocols still presents high variability (Baruselli et al., 2004; Colazo et al., 2004). The different pregnancy rates obtained with hormonal treatments can be associated, among other factors, with estrous cycle stage at the beginning of the treatment (Kastelic et al., 2004; Meneghetti et al., 2009), with the inherited individual animal response to the treatment and also with the ovulatory follicle diameter at the moment of FTAI (Perry et al., 2007). Based on these considerations, it becomes evident that the success of gestation establishment is directly associated to the competence and diameter of the ovulatory follicle. Cows which were induced to ovulate small follicles $(<11.5 \mathrm{~mm})$ developed small corpus luteum, which secreted less progesterone (Vasconcelos et al., 2001), and consequently, had lower pregnancy rate (Lamb et al., 2001) and an increase in embryonic death (Perry et al., 2005).

As previously described and reviewed by many authors (Ghaemi et al., 2008; Kleemann et al., 1994; Mann et al., 2006), the luteal progesterone post artificial insemination is essential to the appropriate establishment and maintenance of pregnancy (Mann \& Lamming, 1999; McDonald et al., 1952). The ability of the corpus lutem to produce progesterone depends on the number of granulosa cells of the ovulatory follicle (McNatty et al., 1979), which is directly related with follicle diameter. The larger the follicle, the higher the number of granulosa cells and consequently, the higher the esteroidogenic potential of the future corpus luteum. Curiously, the ovulation induction of large follicles is also related to low fertility (Austin et al., 1999; Fricke et al., 1997; Shaham-Albalancy et al., 2000; Utt et al., 2003); notwithstanding, after luteinization, corpora lutea originated from these follicles secrete higher concentrations of progesterone (Pfeifer et al., 2009).

Although the effect of the diameter of ovulatory follicles on fertility of cows traditionally inseminated (normal estrous cycle) (Perry et al., 2007) or fixed-time inseminated (Sá Filho et al., 2010) have been described; no study has evaluated such effect in cows subjected to low progesterone protocols of FTAI. Based on these considerations, the objective of this study was to evaluate the relationship between pregnancy rate and size of the ovulatory follicle, 
size of the corpus luteum and serum progesterone after FTAI with low progesterone protocols.

\section{Material and Methods}

A total of 93 lactating beef cows (Bos Taurus, mainly Hereford and Hereford Charolais), 60 to 75 days postpartum, between 3 and 14 years old, body condition score of $3.4 \pm 0.4$ (ranging from 2.5 to 4.0 ) and 450 to $650 \mathrm{~kg}$ of weight, were used in this study. The animals were kept on pasture, with access to water, salt, and a mineral mixture ad libitum. Before the start of the experiment, ovarian function was assessed twice (10 d apart) by transrectal ultrasonography (Aloka SSD-900 with 7.5 MHz linear-array transducer; Aloka, Tokyo, Japan). Only cows in which a corpus luteum was detected in one or both examinations were included in the study. All animals received $500 \mu \mathrm{g}$ of cloprostenol i.m. (PGF, Estrumate, Schering-Plough Animal Health, Pointe-Claire, QC, Canada) twice, $11 \mathrm{~d}$ apart. Ten days after the second PGF injection (Day 0), corresponding to approximately 5 to $8 \mathrm{~d}$ after ovulation, all cattle received an intravaginal progesterone-releasing device (Cue-Mate; Bioniche Animal Health, Belleville, ON, Canada). Cows received another luteolytic dose of PGF on Day 0. Concurrently, cows were given $1.5 \mathrm{mg}$ i.m. estradiol benzoate (Sigma Chemical Co., St. Louis, MO, USA) dissolved in canola oil. Each Cue-Mate was equipped with 1 progesteronereleasing pod (containing $0.78 \mathrm{~g}$ progesterone) and a second blank pod. It was expected that plasma progesterone concentrations below $1 \mathrm{ng} / \mathrm{mL}$ would be achieved $2 \mathrm{~d}$ after the insertion of these devices in cows without a functional corpus luteum (Rogan et al., 2007). On day 8 , the intravaginal devices were removed. The FTAI was performed 54 to 56 hours later, and cows were concurrently given $12.5 \mathrm{mg}$ of porcine LH(LHp) i.m. (Lutropin-V, Bioniche Animal Health, Belleville, ON, Canada).

Transrectal ultrasonography was performed on Day 10 (before insemination) to determine the diameter of ovulatory follicle, on Day 17 to determine the diameter of the corpus luteum and the ovulation rate, and on Day 38 to detect pregnancy. The largest follicle present in the ovary, at the moment of FTAI, was classified as ovulatory only when a corpus luteum was detected, on Day 17, at the same position and in the same ovary.

Blood samples were collected by coccygeal venipuncture into $10 \mathrm{~mL}$ heparinized tubes (Vacutainer system; BectonDickinson, Franklin Lakes, NJ, USA) and were immediately centrifuged ( $1500 \mathrm{x}$ g for $15 \mathrm{~min}$ ); the plasma was collected and stored at $-20^{\circ} \mathrm{C}$. Blood samples were collected on Day 4 , in a subgroup of cows $(n=35$; expected day of follicular emergence) to ensure that cows were under low progesterone concentrations, and on Day 17 in all cows (7 $\mathrm{d}$ after induction of ovulation) to determine serum progesterone.

Serum progesterone was analyzed by radioimmunoassay in solid phase, with a minimum detection limit of $0.1 \mathrm{ng} / \mathrm{mL}$, according to Del Vecchio et al. (1995). The standard curve of progesterone was obtained using the standard samples of a progesterone diagnostic kit (Coat-a-Count; Diagnostic Products Corporation, Los Angeles, CA, USA). Progesterone was extracted with $3 \mathrm{~mL}$ of hexane from aliquots of $200 \mu \mathrm{L}$ of plasma. The intra-assay coefficients of variation $(\mathrm{CV})$ were $12.3 \%$ and $8.2 \%$; and the inter-assay $C V$ was $15.0 \%$ and $14.0 \%$ for patterns of low $(0.24 \mathrm{ng} / \mathrm{mL})$ and high progesterone $(0.93 \mathrm{ng} / \mathrm{mL})$, respectively.

All statistical analyses were performed with the SAS software (Statistical Analyses System, version 9.0). To evaluate the influence of the follicle diameter on reproductive performance, the largest follicle detected in the ovary at time of FTAI was considered the ovulatory follicle. Due to low statistical power in such small amount of cows $(n=93)$, the follicles were separated in categories according to the pregnancy rate. The pregnancy rate for each follicle size was determined and its standard deviation from the average pregnancy rate was calculated. After that, follicles were grouped according to their deviation from the average pregnancy rate. This procedure enables the determination of which size of follicle was increasing or decreasing according to the average pregnancy rate. Therefore, the follicles were grouped in one of the five classes: 10-12; $13-15 ; 16-18 ; 19-21$ and $>22 \mathrm{~mm}$. In the initial analysis of single-point measurements (e.g., diameter of corpus luteum and progesterone concentration on Day 17), the statistical model included: age, parity, days postpartum, body condition score, and body weight. Since these variables had no significant effects in the model, they were excluded from the final statistical model and analyzed by one-way ANOVA. The pregnancy rate and the proportion of cows classified into the different follicles category previously described were compared over the ovulatory follicle categories by the Chi-square test. To predict the effect of the diameter of the ovulatory follicle on pregnancy rate, a polynomial regression analysis was used, in which the statistical models were selected according to significance of the regression coefficients $(\mathrm{P}<0.05)$ and by the coefficient of determination. Furthermore, Pearsons correlations were determined for the following pairs of end points: diameter of corpus luteum and progesterone concentration on Day 17, diameter of ovulatory follicle and progesterone concentration on Day 17, and corpus luteum diameter. A 
descriptive analysis (means \pm standard error) was performed to demonstrate the concentration of progesterone on Day 4.

\section{Results and Discussion}

The results of this study support the hypothesis that an optimal size of ovulatory follicle may improve the pregnancy in postpartum beef cows synchronized with low progesterone concentration. In this study, cows with ovulatory follicles ranging from 13-15 $\mathrm{mm}$ of diameter presented higher pregnancy rate than those detected with larger or smaller follicles (Figure $1 \mathrm{~A} ; \mathrm{P}<0.05$ ). In addition, it was possible to detect that the relationship between fertility

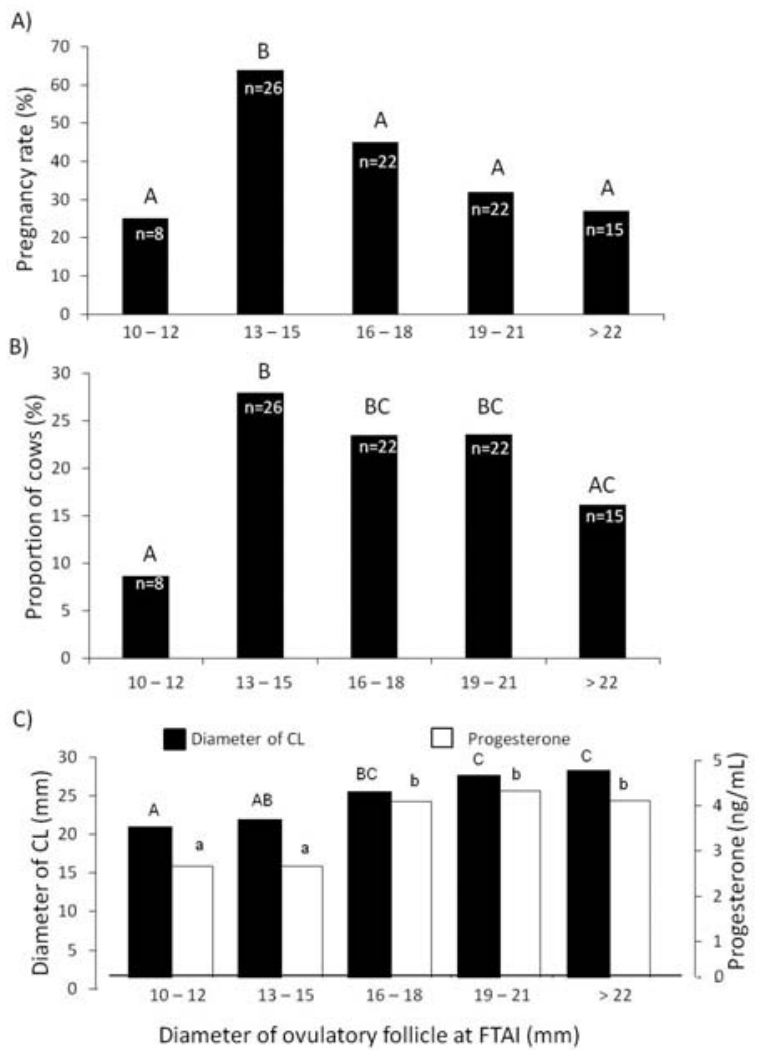

Black bars indicate the size of the corpus luteum (CL) and white bars indicate the progesterone concentration. The number of cows in each follicle category is shown inside the bars from graphs A and B. Different letters indicate difference between categories of ovulatory follicles (Panels A and $\mathrm{B} ; \mathrm{P}<0.05)$. Uppercase letters indicate difference in CL size and lowercase letters indicate difference in progesterone concentration between the categories of ovulatory follicles (Panel C; $\mathrm{P}<0.05$ ). Ovulatory follicles were classified according to their diameter at fixedtime artificial insemination (FTAI).

Figure 1 - Effect of the ovulatory follicle diameter on the pregnancy rate (A), distribution of the ovulatory follicle diameter (B), and CL diameter and progesterone concentration 7 days after FTAI (C) according to the diameter of the ovulatory follicle in lactating Bos taurus beef cows. and diameter of ovulatory follicle presented a quadratic response, whereas the small ( $\leq 12 \mathrm{~mm}$ ) and large follicles ( $\geq 16 \mathrm{~mm}$ ) had lower pregnancy rates (Figure 2 ). The quadratic relationship that exists between the diameter of ovulatory follicle and pregnancy rate in Bos taurus females had been previously described (Perry et al., 2005; Perry et al., 2007; Vasconcelos et al., 2001). However, apparently, in Bos indicus females, this relationship was not detected, because the larger the ovulatory follicle detected at FTAI, the higher the probability of pregnancy (Meneghetti et al., 2009; Sá Filho et al., 2010). Although data regarding the relationship between pregnancy probability and ovulatory follicle diameter had already been described in Bos indicus (Meneghetti et al., 2009; Sá Filho et al., 2010), to the best of our knowledge, there were no reports showing an adequate mathematic model to estimate this relationship in Bos taurus herds.

A higher proportion of cows presented follicles between 13-15 mm, rather than between $10-12 \mathrm{~mm}$ and $>22 \mathrm{~mm}$ of diameter $(\mathrm{P}<0.05$; Figure 1B). However, it is important to take into account that although all cows enrolled in this study were homogeneous regarding body condition score, lactating period and progesterone concentration during synchronization, a high amplitude in the size of ovulatory follicles among cows was detected (ranging from 10 to $24 \mathrm{~mm}$ ). There is no certainty about the nature of this high variation among individuals; however some factors that affect the diameter of follicle in FTAI programs have been already described and might be involved on the high variability detected, such as the interval between follicular emergency and the progestin removal (Utt et al., 2003), and the ovulation that may occurs during progestin based protocols (Kastelic et al., 2004).

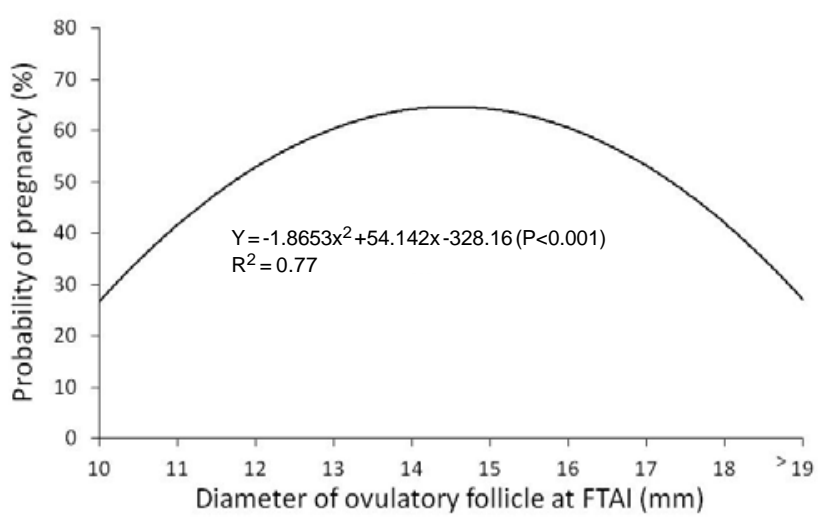

Figure 2 - Effect of the diameter of ovulatory follicle on the probability of pregnancy in lactating Bos taurus beef cows. 
Ovulatory follicles larger than $19 \mathrm{~mm}$ resulted in larger corpus luteus than for cows detected with ovulatory follicles $<15 \mathrm{~mm}$ in diameter $(\mathrm{P}<0.001$; Figure $1 \mathrm{C})$. Similarly, ovulatory follicles $>16 \mathrm{~mm}$ resulted in higher progesterone concentration 7 days after ovulation, than ovulatory follicles $<15 \mathrm{~mm}(\mathrm{P}=0.04$; Figure $1 \mathrm{C})$. As expected, there were significant positive correlations between diameter of ovulatory follicle at FTAI and of corpus luteum on Day 17 $(\mathrm{r}=0.49, \mathrm{P}<0.001)$ and between diameter of corpus luteum and progesterone concentration on Day $17(\mathrm{r}=0.53, \mathrm{P}<0.001)$. In addition, positive correlation between the diameter of ovulatory follicle at FTAI and progesterone concentration on Day 17 was also detected $(\mathrm{r}=0.27, \mathrm{P}=0.01)$.

Some authors suggest that progesterone concentration after artificial insemination is positively related with fertility (Kleemann et al., 1994; Mann \& Lamming, 1999). Cows that have an earlier increase in progesterone concentrations after insemination have a higher chance of maintaining the pregnancy than cows with a slower rise (Diskin \& Morris, 2008). While progesterone is directly related with the size of the dominant follicle and with the steroidogenic ability of the future corpus luteum, apparently, according to this study, in low-progesterone-treated cows, pregnancy rate is more related with an adequate diameter of ovulatory follicle (13-15 mm). Follicles $<11.5 \mathrm{~mm}$ that were induced to ovulate had smaller corpus luteum and secreted less progesterone than cows which ovulated larger follicles (Vasconcelos et al., 2001). The induction of ovulation of small follicles may result in low pregnancy rate (Lamb et al., 2001; Perry et al., 2005 ) and increase in embryonic mortality rate (Perry et al., 2005 ) in postpartum cows subjected to FTAI. The mechanism by which the size of the dominant follicle can negatively affect pregnancy rate can be attributed to the ovulation of an incompetent oocyte, inadequate uterine environment, or both (Busch et al., 2008). A short interval between follicular emergency and induction of ovulation can also be associated to low fertility (Vasconcelos et al., 2001). In contrast, high pregnancy rates $(\sim 70 \%)$ were obtained when ovulatory follicles had about 4 days of follicular dominance (Austin et al., 1999).

Large follicles become large corpora lutea, and consequently, secrete higher concentrations of progesterone and higher fertility could be expected. However, in this study, very large ovulatory follicles were not associated to increased fertility in cows treated with low progesterone. Follicles that grew in a low progesterone environment tended to become persistent follicles and are highly associated with decrease on fertility (Anderson \& Day, 1994; Fike et al., 1997; Sanchez et al., 1993; Wehrman et al., 1993). The progesterone concentrations detected on Day 4
$(0.53 \pm 0.27 \mathrm{ng} / \mathrm{mL})$ confirm that cows were under low progesterone concentrations during the hormonal treatment. Unfortunately, the authors of the present study were not able to perform daily ultrasound examination in all cows to ensure that the very large follicles detected were from persistent follicles. Females subjected to low progesterone concentration, in the absence of a corpus luteum, have an increase in LH pulsatility, similar to the LH secretion detected during the follicular phase of the estrous cycle (Kojima et al., 1992; Roberson et al., 1989). The increased frequency of LH pulses apparently impairs the temporal relationship between oocyte and preovulatory follicle maturation (Austin et al., 1999). Persistent follicles developed in low progesterone environment demonstrated a reduction on viability of oocytes (Revah \& Butler, 1996), perhaps because of the prematuration of the oocyte (Mihm et al., 1999). Oocytes from persistent follicles may even be fertilized, but their developmental competence is compromised, and consequently, decreased embryonic development (Ahmad et al., 1995). Furthermore, structural changes in the oocyte, as premature expansion of cumulus cells and germinal vesicle breakdown have been observed in oocytes from persistent follicles (Mihm etal., 1994; Revah \& Butler, 1996).

\section{Conclusions}

Although large ovulatory follicles result in larger corpora lutea and, consequently, higher progesterone concentration, post-partum cows synchronized with low progesterone that ovulated follicles between 13 and $15 \mathrm{~mm}$ in diameter at timed artificial insemination were more likely to become pregnant than cows with follicles that ovulate with more extreme diameters.

\section{Acknowledgements}

The authors thank the University of Saskatchewan (USASK) for the laboratory support at the hormone analysis. The authors thank especially CAPES (Ministry of Education) for financial support and Schering-Plough Animal Health for their support and the donation of Estrumate (Cloprostenol). The authors also thank Dr. Vitor Roll for the statistical support and the research team of NUPEEC from the Faculty of Veterinary of Universidade Federal de Pelotas.

\section{References}

AHMAD, N.; SCHRICK, F.N.; BUTCHER, R.L. et al. Effect of persistent follicles on early embryonic losses in beef cows. Biology Reproduction, v.52, n.5, p.1129-1135, 1995. 
ANDERSON, L.H.; DAY, M.L. Acute progesterone administration regresses persistent dominant follicles and improves fertility of cattle in which estrus was synchronized with melengestrol acetate. Journal of Animal Science, v.72, n.11, p.2955-2961, 1994.

AUSTIN, E.J.; MIHM, M.; RYAN, M.P. et al. Effect of duration of dominance of the ovulatory follicle on onset of estrus and fertility in heifers. Journal of Animal Science, v.77, n.8, p.2219-2226, 1999.

BARUSELLI, P.S.; REIS, E.L.; MARQUES, M.O. et al. The use of hormonal treatments to improve reproductive performance of anestrous beef cattle in tropical climates. Animal Reproduction Science, v.82-83, p.479-486, 2004

BUSCH, D.C.; ATKINS, J.A.; BADER, J.F. et al. Effect of ovulatory follicle size and expression of estrus on progesterone secretion in beef cows. Journal of Animal Science, v.86, n.3, p.553-563, 2008.

COLAZO, M.G.; KASTELIC, J.P.; WHITTAKER, P.R. et al. Fertility in beef cattle given a new or previously used CIDR insert and estradiol, with or without progesterone. Animal Reproduction Science, v.81, n.1-2, p.25-34, 2004.

DEL VECCHIO, R.; SUTHERLAND, W.D.; CONNOR, L. A solid phase enzyme-immunoassay for the determination of progesterone in bovine, ovine and porcine plasma. Canadian Journal of Animal Science, v.75, p.525-529, 1995.

DISKIN, M.G.; MORRIS, D.G. Embryonic and early foetal losses in cattle and other ruminants. Reproduction in Domestic Animals, v.43, p. $260-267,2008$

FIKE, K.E.; WEHRMAN, M.E.; BERGFELD, E.G. et al. Prolonged increased concentrations of 17 beta-estradiol associated with development of persistent ovarian follicles do not influence conception rates in beef cattle. Journal of Animal Science, v.75, n.5, p.1363-1367, 1997.

FRICKE, P.M.; AL-HASSAN, M.J.; ROBERTS, A.J. et al. Effect of gonadotropin treatment on size, number, and cell proliferation of antral follicles in cows. Domestic Animal Endocrinology, v.14, n.3, p.171-180, 1997.

GHAEMI, S.R.; SALEHNIA, M.; VALOJERDI, M.R. The effect of progesterone and exogenous gonadotropin on preimplantation mouse embryo development and implantation. Experimental Animals, v. 57, n.1, p.27-34, 2008

KASTELIC, J.P.; COLAZO, M.G.; SMALL, J.A. et al. Ovarian follicular dynamics in cows treated with a CIDR, estradiol and progesterone late in the estrous cycle. In: INTERNATIONAL EMBRYO TRANFER SOCIETY ANNUAL CONFERENCE, 30., 2004. Portland, OR. Anais... Portland: IETS, 2004. p.129-130.

KLEEMANN, D.O.; WALKER, S.K.; SEAMARK, R.F. Enhanced fetal growth in sheep administered progesterone during the first three days of pregnancy. Journal of Reproduction and Fertility, v.102, n.2, p.411-417, 1994.

KOJIMA, N.; STUMPF, T.T.; CUPP, A.S. et al. Exogenous progesterone and progestins as used in estrous synchrony regimens do not mimic the corpus luteum in regulation of luteinizing hormone and 17 beta-estradiol in circulation of cows. Biology of Reproduction, v.47, n.6, p.1009-1017, 1992.

LAMB, G.C.; STEVENSON, J.S.; KESLER, D.J. et al. Inclusion of an intravaginal progesterone insert plus $\mathrm{GnRH}$ and prostaglandin F2alpha for ovulation control in postpartum suckled beef cows. Journal of Animal Science, v.79, n.9, p.2253-2259, 2001.

MANN, G.E.; FRAY, M.D.; LAMMING, G.E. Effects of time of progesterone supplementation on embryo development and interferon-tau production in the cow. Veterinary Journal, v. 171, n.3, p.500-503, 2006

MANN, G.E.; LAMMING, G.E. The influence of progesterone during early pregnancy in cattle. Reproduction in Domestic Animals, v.34, p.269-274, 1999

MCDONALD, L.E.; NICHOLS, R.E.; MCNUTT, S.H. Studies on corpus luteum ablation and progesterone replacement therapy during pregnancy in the cow. American Journal of Veterinary Research, v.13, n.49, p.446-451, 1952
MCNATTY, K.P.; SMITH, D.M.; MAKRIS, A. et al. The microenvironment of the human antral follicle: interrelationships among the steroid levels in antral fluid, the population of granulosa cells, and the status of the oocyte in vivo and in vitro. Journal of Clinical Endocrinology and Metabolism, v. 49 , n.6, p.851-860, 1979.

MENEGHeTti, M.; SÁ FILHO, O.G.; PERES, R.F. et al. Fixedtime artificial insemination with estradiol and progesterone for Bos indicus cows. I: basis for development of protocols Theriogenology, v.72, n.2, p.179-189, 2009

MIHM, M.; BAGUISI, A.; BOLAND, M.P. et al. Association between the duration of dominance of the ovulatory follicle and pregnancy rate in beef heifers. Journal of Reproduction and Fertility, v.102, n.1, p.123-130, 1994

MIHM, M.; CURRAN, N.; HYTTEL, P. et al. Effect of dominan follicle persistence on follicular fluid oestradiol and inhibin and on oocyte maturation in heifers. Journal of Reproduction and Fertility, v.116, n.2, p.293-304, 1999.

PERRY, G.A.; SMITH, M.F.; LUCY, M.C. et al. Relationship between follicle size at insemination and pregnancy success. Proceedings of the National Academics of Science of the United States of America, v.102, n.14, p.5268-5273, 2005

PERRY, G.A.; SMITH, M.F.; ROBERTS, A.J. et al. Relationship between size of the ovulatory follicle and pregnancy success in beef heifers. Journal of Animal Science, v.85, n.3, p.684-689, 2007.

PFEIFER, L.F.M.; MAPLETOFT, R.J.; KASTELIC, J.P. et al. Effects of low versus physiologic plasma progesterone concentrations on ovarian follicular development and fertility in beef cattle. Theriogenology, v.72, p.1237-1250, 2009

REVAH, I.; BUTLER, W.R. Prolonged dominance of follicles and reduced viability of bovine oocytes. Journal of Reproduction and Fertility, v.106, n.1, p.39-47, 1996.

ROBERSON, M.S.; WOLFE, M.W.; STUMPF, T.T. et al. Luteinizing hormone secretion and corpus luteum function in cows receiving two levels of progesterone. Biology of Reproduction, v.41, n.6, p.997-1003, 1989

ROGAN, D.; MARTINEZ, M.F.; BO, G.A. et al. Progesterone release patterns from Cue-Mate in comparison to other intravaginal progesterone-releasing devices in lacting dairy cows. In: INTERNATIONAL EMBRYO TRANFER SOCIETY ANNUAL CONFERENCE, 33., 2007, Kyoto. Anais... Kyoto: IETS, 2007. p. 122 .

SÁ FILHO, M.F.; CRESPILHO, A.M.; SANTOS, J.E. et al. Ovarian follicle diameter at timed insemination and estrous response influence likelihood of ovulation and pregnancy after estrous synchronization with progesterone or progestin-based protocols in suckled Bos indicus cows. Animal Reproduction Science, v. 120, n.1-4, p.23-30, 2010.

SANCHEZ, T.; WEHRMAN, M.E.; BERGFELD, E.G. et al Pregnancy rate is greater when the corpus luteum is present during the period of progestin treatment to synchronize time of estrus in cows and heifers. Biology of Reproduction, v.49, n.5, p.1102-1107, 1993 .

SHAHAM-ALBALANCY, A.; ROSENBERG, M.; FOLMAN, Y. et al. Two methods of inducing low plasma progesterone concentrations have different effects on dominant follicles in cows. Journal of Dairy Science, v.83, n.12, p.2771-2778, 2000

UTT, M.D.; JOUSAN, F.D.; BEAL, W.E. The effects of varying the interval from follicular wave emergence to progestin withdrawal on follicular dynamics and the synchrony of estrus in beef cattle. Journal of Animal Science, v.81, n.6, p.1562-1567, 2003.

VASCONCELOS, J.L.; SARTORI, R.; OLIVEIRA, H.N. et al. Reduction in size of the ovulatory follicle reduces subsequen luteal size and pregnancy rate. Theriogenology, v.56, n.2, p.307-314, 2001

WEHRMAN, M.E.; ROBERSON, M.S.; CUPP, A.S. et al. Increasing exogenous progesterone during synchronization of estrus decreases endogenous 17 beta-estradiol and increases conception in cows. Biology of Reproduction, v.49, n.2, p.214-220, 1993. 